\section{The Influence of Nutritional Risk in Elderly Patients Hospitalized for Bone Fracture}

Presented at 1st International Online BioMedical Conference ORIGINAL

\section{Abstract}

Introduction: Bone fractures in older adults involve hospitalization and surgical intervention, aspects that have been related to functional and cognitive impairment. Several variables have been studied as moderators in how these patients evolve, such as nutritional status. However the implications of nutritional status in the subsequent evolution of the hospitalized elderly, has not been studied to date.

Objective: In the present study the authors analyze the relationship between the nutritional status, and diferent variables related to the evolution of older adults who have undergone surgery after a bone fracture.

Method and instruments: One hundred-seventy six elderly (aged 65-105 years; 138 females and 38 males) participated in the study. Participants' consent was obtained according to the Declaration of Helsinki. The following questionnaires were administered: Phototest, Auditory Verbal Learning Test of Learning Potential (AVLT-PA) and Mini Nutritional Assessment (MNA). The questionnaires was administered at the three months of the hospitalization.

Results: The elders's nutritional state showed a significant relationship with cognitive decline $(r=.171, p=.038)$, and with cognitive plasticity $(r=.238, p<.010)$. Furthermore, those elderly patients at risk of malnutrition have a higher cognitive decline at the three months of the hospitalization ( $t=-3.808, p=.000$ ) and worse cognitive plasticity $(t=-3.096, p=.004)$.
M. J. Calero-García ${ }^{1}$

A. R. Ortega Martínez ${ }^{2}$

E. Navarro Gonzalez ${ }^{3}$

M. D. Calero 3

1 Faculty of Health Sciences, University of Jaén, Spain.

2 Department of Psychology, University of Jaén, Spain.

3 Faculty of Psychology, University of Granada, Spain.

\section{Contact information:}

\section{J. Calero-García.}

Address: Facultad de CC de la Salud, Universidad de Jaén. Campus Lagunillas 23071 Jaén (Spain).

”mjcalero@ujaen.es

\section{Keywords}

Nutritional Risk; Hip Fracture, Cognitive Plasticity, Old Age. 


\section{Introduction}

In the area of healthcare, one of the most frequent problems in older adults has to do with bone fractures, generally caused by falls, osteoporosis, etc. [1]. This condition accounts for one-fourth of hospitalizations, where the length of hospital stay varies as a function of several variables [2]. As these authors indicate, in recent years, traumatology problems and especially broken hips have increased by $25 \%$ in the hospital admissions of seniors over age 65 in Spain. In this context, one especially significant phenomenon in gerontology research is the loss of functionality, characterized as the loss of independence and increased cognitive decline, sometimes associated with the lack of mobility brought on by a bone fracture, whether a hip [1] or another part of the anatomy $[3,4]$.

On the other hand, generally people with hip fractures, which are often fragile and senior age are malnourished at the time of the fracture $[5,6]$. Psychological, physical, economic, medical and social cognitive influences may contribute to the risk of malnutrition. Surveys of dietary intake in patients recovering from a hip fracture in hospital have recorded suboptimal intakes $[6,7,8]$.

Malnutrition causes mental apathy, loss of muscle mass, decreased muscle strength and deterioration of cardiac function [9]. All these factors will cause impaired mobility and increase the tendency to develop postoperative medical complications (eg, pneumonia, decubitus ulcers, deep vein thrombosis) and hamper recovery in the hospital and later [10]. Malnutrition also impairs the immune response, increasing the risk of postoperative infections [11]. Poor nutritional status is associated with an increased risk of pressure ulcers after hip fracture [12].

Undernutrition in older persons has been linked with longer hospital stays and greater mortality, and up to 71 percent of older persons requiring hospitalization are believed to be at nutritional risk. [13]. Brown (1992) [14] reported a shorter stay in the hospital for acute disease for the persons no nutritional risk (27 days versus 48 days: mean difference -21.00 days; $99 \% \mathrm{Cl}$ : -65.15 to 23.15 días). Delmi (1990) [15] reported a median hospital stay significantly lower from the statistical point of view acute wards and rehabilitation for patients group no nutritional risk.

The therapeutic objective of the acute phase is to minimize the impact of the fracture on the clinical, physical, mental and social spheres of the patient. Several healthcare professionals must act in coordinated fashion to intervene in this process -traumatologists, anesthetists, rehabilitation specialists, nurses, physiotherapists, occupational therapists, social workers, etc.- and one of the variables to consider is the nutritional status of the hospitalized patient.

To know the real influence of nutritional status in patient functional and cognitive impairment and subsequent recuperation, the analyzing the variables involved in the patient's recovery or decline constitutes a very relevant research objective. Some studies show that this variable can predict later cognitive decline in healthy older adults and/or those with slight cognitive decline [16, 17, $18,19]$, or can predict their response to cognitive training [20].

Moreover, the degree of plasticity has been associated with the cognitive state of older adults, where recent studies show how adults with normal or optimal aging benefit from high levels of cognitive plasticity [21, 22]. Elsewhere, plasticity has been associated with an active life style [21] as well as with a high level of independence in activities of daily life, and with better quality of life $[23,24]$.

In the studies that have analyzed variables related to cognitive and functional decline associated with hospitalization and recovery thereafter, several authors have found greater functional loss associated with variables such as age $[25,26]$, prolonged rest [27], decubitus [28], pain produced by the sur- 
gery [29], the presence of other illnesses [30] and the number of hospitalization days prior to the surgery [31]. Other authors associate functional loss with the nutritional status [32].

\section{Method}

\section{Participants}

A total of 176 older adults from the province of Jaén (southern Spain) participated in the study. To be included in the study, patients had to be over 65 and be hospitalized for bone fracture. The mean age was 78.55 years $(S D=8.55$, range 65105 years). As for gender, 138 were women and 38 were men.

Level of education was distributed as follows: 91.7\% had no schooling or had primary education, $5.7 \%$ secondary education, and $2.5 \%$ university education.

\section{Instruments}

Semistructured interview: patient data sheet created for this study, where information was recorded on personal health, biological and social variables.

The Auditory Verbal Learning Test-Learning Potential (AVLT-LP) [33]; adapted to Spanish [34], was used for assessing cognitive plasticity. This is a version of the classic Verbal Memory test by Rey (1964) [35], its traditional version consisting of the presentation of fifteen common words that the participant must repeat immediately after hearing them. The list is presented a total of five times, and on each occasion the words remembered are recorded. In the learning potential version, the wordlist is presented six times. The first two times are a pre-test, following the standard format, the next two are for training and include feedback on execution, motivation, reinforcement and repetition of words not remembered, and the last two times are a post-test, again following the standard format. Applying the test in this fashion provides different markers. In this study we have worked with the following: 1) direct scored obtained on each test trial, 2) AVLT-LP delayed memory: number of words remembered after finishing the test and then performing other tasks by way of interference, and 3) AVLT-LP gain score: posttest minus pretest. This gain score indicates the amount of improvement after the training phase, and several studies establish this score as a measure of learning ability or cognitive plasticity in healthy older adults or in older adults with cognitive decline [36, 37, 38,39 ] and in other populations such as persons with schizophrenia or dementia [40]. Based on the gain score, persons are classified into two groups: with and without cognitive plasticity (a function of whether improvement on the posttest is or is not greater than 1.5 standard deviations with respect to the pretest). The test has also been validated by several authors with Spanish population similar to that participating in this study $[36,37]$.

Test of photos or Phototest [41]. The Test of the photos is a brief cognitive test that evaluates the ability to remember six elements which have previously been shown to the patient and asked him to name. Among denomination and remember a verbal fluency task, in which the participant must recall names of people grouped by gender [42] is inserted. The breakpoints of Phototest for diagnosis of cognitive impairment are 28/29, 28 or less "cognitive impairment" 29 or more "nondeterioration". The discriminative validity of the test is good Pictures equal to or higher than the test of widespread use in this environment with the advantage that it is not influenced by the educational level.

Mini Nutritional Assessment (MNA) [43]. This test evaluate nutritional risk. It consists of 18 questions grouped into four sections, which collect anthropometric data, global assessment, dietary intake, and subjective evaluation. The Spanish Society of Parenteral and Enteral Nutrition recommends MNA specifically for elderly patients, including severely 
limited groups of different countries, including ours [44]. It does not require skilled personnel or complex biochemical or anthropometric measurements [45].

\section{Procedure}

The research was carried out in a hospital in Jaén (southern Spain). Once the project was explained to and approved by the hospital ethics committee, the principal investigator checked on a daily basis for patients above 65 years of age who were admitted with a bone fracture diagnosis. Patients who met the study inclusion criteria were visited personally by the researchers, who explained to them the objective of the study and requested their informed consent (Helsinki Declaration, 2004), given by their signature to that effect. Once the participant gave his or her consent, the relevant medical history was collected. At 90 days after release from hospital, the home visit was carried out. During this visit other sociodemographic data were collected, and new functional and cognitive assessments were carried out, using all the tests described in the previous section on instruments.

Regarding the cognitive plasticity, as a function of the gain score, participants were classified as having plasticity (gain score on the AVLT-LP of 3 or more) or not having plasticity (gain score below 3 on the AVLT-LP).

\section{Design and statistical analyses}

The design was a transversal correlational study. The dependent variables were the measurements obtained with the instruments described. Associations between variables were computed by Pearson correlations. To prove the possible existence of differences, according to nutritional risk, we use Student T-test. The effect size was estimated using Cohen's $d$. Statistical analyses were performed using the $R$ statistical software package ( $R$ Foundation for Statistical Computing, Vienna, Austria) and statistical decisions were taken at a level of significance of.05 or lower.

\section{Results}

In the overall sample, the elderlys's nutritional state was positively associated with cognitive decline $(r=.171, p=.038)$, and with cognitive plasticity $(r=.238, p<.010)$. Furthermore, as a function of the scores obtained on the MNA, older adults were classified as patients with nutritional risk (scores lower or equal than 11), and no nutritional risk (scores higher than 12). In order to verify whether there were differences between these groups with regard to cognitive decline and plasticity, we carried out a comparison of the mean values. The outcomes revealed significant differences between both groups in cognitive decline ( $t=-3.808, p=.000, d=.63)$ and cognitive plasticity $(t=-3.096, p=.004, d=1.13)$. Thereby, those elderly patients at risk of malnutrition have a higher cognitive decline and worse cognitive plasticity.

\section{Discussion and Conclusions}

According to the results of this study, elderly patients's nutritional state show a significant rela-

Table 1. Descriptive statistics for variables.

\begin{tabular}{|c|c|c|c|c|c|c|}
\hline & \multicolumn{2}{|c|}{ Total Group } & \multicolumn{2}{|c|}{ No risk malnutrition Group } & \multicolumn{2}{|c|}{ Risk malnutrition Group } \\
\hline & M & SD & M & SD & M & SD \\
\hline Cognitive Decline & 28.79 & 9.50 & 30.99 & 8.80 & 24.30 & 7.68 \\
\hline Cognitive Plasticity & 3.33 & 1.77 & 3.45 & 1.76 & 2.36 & 1.28 \\
\hline Nutritional Status & 11.75 & 1.66 & 12.53 & 0.88 & 9.26 & 0.98 \\
\hline
\end{tabular}


tionship with the cognitive decline and cognitive plasticity. As other authors have postulated [18, 19] our data indicate that cognitive decline is greater and cognitive plasticity is lower with the nutritional state worse. In addition, our results present significant differences between the groups of nutritional risk and no nutritional risk, with the latter group showing significantly worse scores on cognitive functionality indicators.

Undernutrition in older persons has been linked with longer hospital stays and greater mortality. To date, studies have shown that nutritional state moderates the immune response [11], increased risk of pressure ulcers after hip fracture [12], well as longer hospital stays and greater mortality but no differences were noted among the groups regarding functional or cognitive status [13]. The results of the study extend this evidence by showing that nutritional status also moderates the cognitive status of older people.

Regarding the limitations of the study, the sample size is small for a moderating study, which may have compromised the statistical power. In view of this limitation, the results should be treated with caution and considered preliminary; there is a need for replication using larger samples. Second, the sample is comprised of participants at a single hospital, and that we have not taken into account other variables that may be relevant as the level of education, which could limit the generalizability of the results. For these reasons it is therefore important to replicate the findings with other samples of hospitalized elderly.

\section{Disclosure}

All authors report no conflict of interest.

\section{References}

1. [1] Beaupre L., Cinats J., Jones C., Scharfenberger A., Johnston D., Senthilselvan A. Does functional recovery in elderly hip fracture patients differ between patients admitted from longterm care and the community? J Gerontol A Biol Sci Med Sci 2007; 62A:1127-33

2. Castro-Cristóbal C., García- Martinez, M.T. Cuidados en el paciente traumatológico. In Guillen Llera, F., Perez del Molino Martin, J., Petidier Torregrossa, R. Editors. Síndromes y cuidados en el paciente geriátrico. Barcelona: Elservier Masson, 2008; p.385-96.

3. Abianza P., Navarro J. L., Romero L., León M., Sánchez-Jurado P., Domínguez, L. Upper extremities function as an independent predictor of adverse events in hospitalized elderly. Gerontol 2007; 1: 267-73.

4. Luis P. A., León R. M., Domínguez P. M. Upper extremity function, an independent predictor of adverse events in hospitalized elderly. Gerontol 2007; 53:267-73.

5. Bachrach-Lindstrom M., Unosson M., Ek A.C., Arnqvist H.J. Assessment of nutritional statis using biochemical and anthropometric variables in a nutrutional intervention study of womwn with hip fracture. Clin Nutr 2001; 20:217-23.

6. Lumbers M., New S.A., Gibson S., Murphy M.C. Nutritional syatus in elderly female hip fracture patients: comparison with an age-matched home living group attendeund day centres. $\mathrm{Br}$ J Nutr 2001; 85: 733-40.

7. Nematy M., Hickson M., Brynes A.E., Ruxton C., Frost G.S. A pilot survey to investigate the nutritional status of patients with fractured neck of femur and level of nutritional support provided durinf treatment. Proc Nutr Soc 2004; 63: 77A

8. Patterson B.M., Cornell C.N., Carbone B., Levine B., Chapman D. Protein depletion and metabolic stress in elderly patients who have a fracture of the hip. J Bone Joint Sur Ame 1992; 74: 25160.

9. Avenell A., Handoll H.H.G. Nutritional supplementation fofr hip fracture aftercare in older people. Cochrane Database f Systematic Review 2010; Issue 1. Art, No,: CD001880. DOI: 10.1002/14651858.CD001880.pub5.

10. Lennard-Jones J. E. Editor. A positive approach to nutrition as treatment. Report on the role of enteral and parenteral feeding in hospital and at home. London: Kings's Fund Centre 1992. ISBN 1857170164.pbk

11. Lesourd B.M. Nutrition and immunity in the elderly: modification of immune responses with nutritional treatments. Am J Clin Nutr 1997; 66:478S-84S

12. Lindholm C., Sterner E, Romanelli M., Pina E., Torra y Bou J., Hietanen $\mathrm{H}$. Et al. Hip fracture ans pressure ulcers -the PanEuropean Pressure Ulcer Study -intrinsic and extrinsic risk factors. Int Wound J 2008; 5: 15-28. 
13. Ooi C., Loke S., Yassin Z., Hamid T. Hidratos de carbono para mejorar el rendimiento cognitivo de los adultos mayores que viven de forma independiente con función cognitiva normal o con deficiencia cognitiva leve (Revision Cochrane traducida). Cochrane Database of systematic Reviews. Issue 4. Art. No.: CD 007220. DOI: 10.1002/14651858.CD007220.

14. Brown K.M., Seabrook, N.A. Effect of nutrition on recovery after fractured femur. Medical Audit News 1992; 2: 10-2

15. Delmi M., Rapin C.H., Bengoa J.M., Delmas P.D. Vasey H., Bonjour J.P. Dietary supplementation in elderly patients with fractured neck of the femur. Lancet 1990; 335: 1013-6.

16. Baltes M., Kuhl K.P., Sowarka D., Gutzman H. Potential of cognitive plasticity as a diagnostic instrument: a cross-validation and extension. Psychol Aging 1995; 10: 167-72.

17. Baltes M., Raykov T. Prospective validity of cognitive plasticity in the diagnosis of mental status: a structural equation model. Neuropsychol 1996; 10:549-56.

18. Calero M.D.,Navarro E. Relationship between Plasticity, Mild Cognitive Impairment and Cognitive Decline. Arch Clin Neuropsychol 2004;19: 653-660.

19. Raykov T., Baltes M.M., Neher K.M., Sowarka, D. A comparative study of two psychometric approaches to detect risk status for dementia. Gerontol 2002; 48: 185-193.

20. Calero M.D., Navarro, E. (2007). Effectiveness of a memory training programme in the maintenance of status in elderly people with and without cognitive decline. Psychol Spain 2007; 11:106-112.

21. Calero M.D., Navarro E., Muñoz-Manzano, L. Influence of level of activity on cognitive plasticity in elderly persons. Arch Gerontol Geriatr 2007; 45: 307-318.

22. Vance DE, Crowe M. A proposed model of neuroplasticity and cognitive reserve in older adults. Activities, Adaptation and Aging. 2006;30(3):61-79. doi: 10.1300/J016v30n03_04.

23. Calero M.D., Navarro, E. Differences in cognitive performance, level of dependency and quality of life (QoL), related to age and cognitive status in a sample of Spanish old adults under and over 80 years of age. Arch Gerontol Geriatr 2011; 53: 292-97.

24. Navarro E., Calero M.D., Lopez A., Gómez A., Torres, I., CaleroGarcía, M. J. Nivel de dependencia en la vida diaria y plasticidad cognitiva en la vejez. Escritos De Psicología 2008; 2: 74-84.

25. Covinsky K. E., Palmer, R. M. Loss of independence in activities of daily living in older adults hospitalized with medical illnesses: Increased vulnerability with age. J Am Geriatr Soc 2003;51: 451458.

26. Varela L., Chavez H., Galvez M., Mendez, F. Características del deterioro cognitivo en el adulto mayor hospitalizado a nivel nacional. Revista de la Sociedad Peruana de Medicina Interna 2004; 17: 37-42.
27. Gutiérrez J., Domínguez V., Solano, J. J. Deterioro funcional secundario a la hospitalización por enfermedad aguda en el anciano. Análisis de la incidencia y de los factores asociados. Rev Clín Esp 1999; 1: 418-423.

28. Delgado-Parada E., Suárez-García F. N., Miniana-Climient, J. C., Medina-García, A.,López-Gaona, V., Gutiérrez-Vara, S., et al. Variables asociadas al deterioro funcional al alta y al los tres meses, en ancianos hospitalizados por insuficiencia cardiaca. Rev Esp Geriatr Gerontol 2009; 2: 66-72.

29. Feldt, K., Finch M. Older adults with hip fracatures: Treatment of pain following hospitalization. J Gerontol Nurs 2002; 28: 27-35

30. Macias-Montero M. C., Guerrero-Díaz M. T., HernándezJiménez, V. Valoración Mental. In F. Guillen Llera, Perez del Molino Martín, J. y R. Petidier Torregrossa, editors Sindromes y cuidados del paciente Geriátrico. Barcelona: Elservier-Masson, 2008; p. 245-260.

31. Calero-García M. J., Ortega A. R., Navarro E., Jimenez C., Calero, D. Impact of admissions for bone fractures on the dependency ratio of adults over 65 years of age in southern Spain. Arch Gerontol Geriatr 2012; 55: 305-9.

32. Lennard-Jones J. (Chair) A Positive Approach to Nutrition as Treatment. London: Kings Fund Centre, 1992.

33. Wiedl, K. H., Wienobst, J., \& Schöttke, H. (1999). Estimating rehabilitation potential in schizophrenic subjects. In H. D. Brenner, W. Boker, R. Genners (Eds.), The treatment of schizophrenia: Status and emerging trends. Bonn: Hogrefe \& Hunber.

34. Calero M.D. (2000). Bases psicológicas de la vejez: Funcionamiento cognitivo. In Fernández-Ballesteros, R. editor. Gerontología Social. Madrid: Pirámide, 2000; p.201-19.

35. Rey, A. L'examen clinique en psychologie. Paris. Presses Universitaires de France. 1964.

36. Calero M.D., Navarro, E. La plasticidad cognitiva en la vejez. Técnicas de Evaluación e intervención. Barcelona: Octaedro, 2006.

37. Fernández-Ballesteros, R. et Zamarron, M.D. Cuestionario breve de Calidad de Vida. CUBRECAVI. Madrid: TEA Ediciones, S.A. 2012

38. Navarro E., Calero M.D. Estimation of cognitive plasticity in old adults using dynamic assessment techniques. J Cogn Educ Psychol 2009;8: 38-51.

39. Navarro-Gonzalez E., Calero-García M.D. Relación entre plasticidad y ejecución cognitiva. El potencial de aprendizaje en ancianos con deterioro cognitivo. 2011; Comunicación oral. Congreso Nacional de Enfermedad de Alzheimer. Almería. 
40. Wiedl K.H., Schöttke H., Calero M.D. Dynamic assessment of cognitive rehabilitation potential in schizophrenic persons and in old people with and without dementia. Eur J Psychol Assess 2001; 17:112-19.

41. Carnero-Pardo C., Montoro Ríos M.T. Evaluación preliminar de un nuevo test de cribado de demencia (EUROTEST). Rev Neurol 2004a; 38: 201-9.

42. Carnero-Pardo C., Montoro-Ríos M.T. (2004b). Test de las fotos. Revi Neurol 2004b; 1: 801-6.

43. Guigoz Y., Vellas B., Garry P.J. Mini Nutritional Assessment: a practical assessment tool for grading the nutritional state of elderly patients Facts Res Gerontol 1994; (suppl 2): 15-60.

44. Sánchez-Muñoz, L.A., Calvo-Reyes, M.C., Majo-Carbajo, Y., Barbado-Ajo, J., Aragón de la Fuente, M.M. \& Artero-Ruiz, E.C. (2010). Cribado nutricional con Mini Nutricional Assessment (MNA) en Medicina Interna. Ventajas e inconvenientes. Rev Clin Esp, 9, 429-437.

45. Ulibarri J.I., Burgos R., Lobo G., Martínez M.A. Planas M. Péres de la Cruz A., et al. Recomendaciones sobre la evaluación del riesgo de desnutrición en los pacientes hospitalizados. Nutr Hosp 2009; 24: 467-72.
Comment on this article:

\section{(f) $[$ in $8+\mathbf{S} P$}

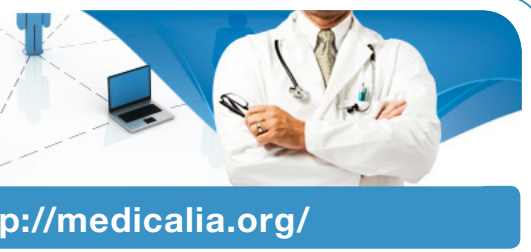

Where Doctors exchange clinical experiences, review their cases and share clinical knowledge. You can also access lots of medical publications for free. Join Now!

\section{Publish with iMedPub}

http://www.imed.pub

International Archives of Medicine is an open access journal publishing articles encompassing all aspects of medical science and clinical practice. IAM is considered a megajournal with independent sections on all areas of medicine. IAM is a really international journal with authors and board members from all around the world. The journal is widely indexed and classified Q1 in category Medicine. 